\title{
炭素存在下における溶銅中の $\mathrm{Cr}$ または $\mathrm{Zr}$ の溶解度
}

\author{
大石敏雄 ${ }^{1}$ 平田敦嗣 2 ,*1 石田 斎 $^{2, * 2}$ 小野勝 敏 ${ }^{3}$
}

\author{
1関西大学工学部材料工学科 \\ 2京都大学大学院工学研究科 \\ 3京都大学大学院エネルギー科学研究科 \\ J. Japan Inst. Metals, Vol. 64, No. 8 (2000), pp. 662-668 \\ (C) 2000 The Japan Institute of Metals
}

\section{Solubility of Chromium or Zirconium in Liquid Copper in the Presence of Carbon}

Toshio Oishi ${ }^{1}$, Atsushi Hirata ${ }^{2, * 1}$, Hitoshi Ishida ${ }^{2, * 2}$ and Katsutoshi Ono ${ }^{3}$

${ }^{1}$ Department of Materials Science and Engineering, Kansai University, Suita 564-8680

${ }^{2}$ Graduate Student, Kyoto University, Kyoto 606-8501

${ }^{3}$ Graduate School of Energy Science, Kyoto University, Kyoto 606-8501

As a fundamental study to prepare copper based $\mathrm{Cu}-\mathrm{Cr}$ and $\mathrm{Cu}-\mathrm{Zr}$ alloys without any inciusions, the solubilities of chromium and zirconium in liquid copper in equilibrium with $\mathrm{C}-\mathrm{Cr}_{3} \mathrm{C}_{2}, \mathrm{Cr}_{3} \mathrm{C}_{2}-\mathrm{Cr}_{7} \mathrm{C}_{3}$ or $\mathrm{C}-\mathrm{ZrC}$ were determined, respectively.

$\mathrm{Cu}-\mathrm{Cr}$ alloys containing higher $\mathrm{Cr}$ concentrations than those expected from the present preparatory experiments were melted in a graphite crucible in an argon atmosphere at temperatures $1573-1873 \mathrm{~K}$. The excess $\mathrm{Cr}$ reacted with carbon to form $\mathrm{Cr}_{3} \mathrm{C}_{2}$ and solubilities of $\mathrm{Cr}$ in the liquid copper in equilibrium with $\mathrm{C}-\mathrm{Cr}_{3} \mathrm{C}_{2}$ were determined; $\log (\operatorname{mass} \% \mathrm{Cr})=-5580 / T+2.97( \pm 0.032)(1573-1873 \mathrm{~K})$

The solubilities of $\mathrm{Cr}$ in the liquid copper under coexistence with $\mathrm{Cr}_{3} \mathrm{C}_{2}$ and $\mathrm{Cr}_{7} \mathrm{C}_{3}$ were also determined using alloys containing higher or lower $\mathrm{Cr}$ concentrations than those expected from the preparatory experiments. The alloys were melted in $\mathrm{BN}$ crucibles with $\mathrm{Cr}_{3} \mathrm{C}_{2}$ or $\mathrm{Cr}_{7} \mathrm{C}_{3}$ in an argon atmosphere at temperatures $1523-1673 \mathrm{~K}$. The solubilities of $\mathrm{Cr}$ in liquid copper in equilibrium with $\mathrm{Cr}_{3} \mathrm{C}_{2}-\mathrm{Cr}_{7} \mathrm{C}_{3}$ are given by

$$
\log (\operatorname{mass} \% \mathrm{Cr})=-3710 / T+2.10( \pm 0.027)(1523-1673 \mathrm{~K})
$$

$\mathrm{Cu}-\mathrm{Zr}$ alloys containing $30 \sim 780$ mass ppm $\mathrm{Zr}$ were melted in a graphite crucible with $\mathrm{ZrC}$ in an argon atmosphere at temperatures $1623-1823 \mathrm{~K}$. The solibilities of $\mathrm{Zr}$ in liquid copper in equilibrium with $\mathrm{C}-\mathrm{ZrC}$ are expressed as $\log ($ mass ppm $\mathrm{Zr})=-9930 / T+7.47( \pm 0.055)(1623-1773 \mathrm{~K})$

Carbon and oxygen solubilities of both $\mathrm{Cu}-\mathrm{Cr}$ and $\mathrm{Cu}-\mathrm{Zr}$ alloys were also obtained and discussed.

(Received March 6, 2000; Accepted July 7, 2000)

Keywords: copper-chromium alloy, copper-zirconium alloy, melting, thermodynamics, solubility, carbon, copper, chromium, zirconium

\section{1. 緒言}

鉰合金の用途としては導電材，バネ材，防食材，耐摩耗性 材などが挙げられるが，IC, LSI, VLSIなどの出現により， 電子材料としての需要も高まっている．電子材料として銅合 金に要求される特性は, 導電性といら単一機能にとどまら ず，著しく多様化したものになった．その中でもリードフレ 一ムに代表されるように導電性と強度が最も重要な要求特性 であり，導電性をできるだけ犠牲にすることなく，かつ強度 をも有する合金化といった方向が，近年になって急速にをの 重要性を増している。

*1 京都大学大学院生, 現在 : 住友金属工業侏 (Graduate Student, Kyoto University, Present address: Sumitomo Metal Industries, Wakayama 640-8404)

*2 京都大学大学院生, 現在 : 神戸製鋼所 (Graduate Student, Kyoto University, Present address: Kobe Steel Company, Kobe 651-2271)
現在, 高強度, 高導電性のリードフレーム材料として, $\mathrm{Cu}-\mathrm{Cr}, \mathrm{Cu}-\mathrm{Zr}$ や $\mathrm{Cu}-\mathrm{Zr}-\mathrm{Cr}$ 合金のような，無酸素銅むるい は高純度銅に活性金属を添加した合金が用いられている1-7). これらは析出硬化型の合金であり熱処理を工夫することによ り高強度が得られ，またダイレクトボンディング性す良いこ とから注目されている。

しかしながら，添加元素である $\mathrm{Cr}, \mathrm{Zr}$ は酸素との親和力 が強く，合金溶製時に酸化物となって析出し，歩留まりが著 しく悪くなるばかりでなく非金属介在物として合金中に残留 する．近年の，集積回路の小型化，高密度化に伴って，合金 は薄肉化, 細線化への方向にあり, 上記介在物は加工時の障 害となることは明らかである。

酸化物の存在しない合金の溶製といら観点からは強力な還 元剤である黑鉛をるつぼとして使用することが考えられる が， $\mathrm{Cr}, \mathrm{Zr}$ は炭素との親和力も極めて強いため, 酸化物の生 成は避忷られても炭化物の生成が新なな問題となる。

そこで本研究では，李ず黒鉛るつぼを用い，炭素存在下に 
括ける溶銅中の $\mathrm{Cr}$ 打よび $\mathrm{Zr}$ の溶解度，つまり $\mathrm{C}-\mathrm{Cr}_{3} \mathrm{C}_{2}$ 市 るいは C-ZrC と平衡する溶銅中の Cr あるは $\mathrm{Zr}$ の溶解度 を求めた。委たCrに関してはさらにボロンナイトライド

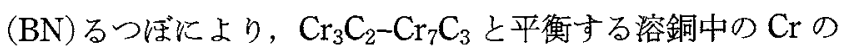
溶解度子求めた。つぎに，これらのデータと各酸化物 $\left(\mathrm{Cr}_{2} \mathrm{O}_{3}, \mathrm{ZrO}_{2}\right)$ の標準生成自由エネルギーのデータを用いて 酸化物の析出しない溶解雲团気条件を明らかにした。

な和，これまで $\mathrm{Cu}-\mathrm{Cr}, \mathrm{Cu}-\mathrm{Zr}$ 合金関する状態図や活量 などの熱力学的研究8-11)や，時効熱処理などの材料学的研 究12-15) は数多くなされているが，合金の溶製の面からの研 究は著者らの知る限り報告されていない。

\section{2. 実験}

\section{1 試 料}

\subsubsection{Cu-Cr 系}

出発試料として，JIS 第一種無酸素銅(純度 $99.99 \%)$ と粒 状クロム(純度99.99\%)を用いた。 すず，表面の污れや酸化 物を除去するために Cu は硝酸 $(1+1), \mathrm{Cr}$ は塩酸 $(1+1)$ で洗 浄した後, 超音波洗浄器により蒸留水, アルコール, アセ卜 ンの順で洗浄し，ドライヤーで冷風乾燥した.

これらの試料よりまず電子ビーム溶解炬を用いて东冷銅 コールドハース上でボタン溶解を行い，Cｒ濃度が約 10 mass\%の第一段母合金約 $20 \mathrm{~g}$ 作製した. 続いて, Mo 発 熱体真空溶解炉により，上記母合金に無酸素銅を添加し，ア ルミナるつぼ中， $1573 \mathrm{~K}$ で溶解することにより $\mathrm{Cr}$ 濃度が $0.4 \sim 1.3$ mass\%の第二段母合金を作製した.

$\mathrm{Cr}_{3} \mathrm{C}_{2}$ 执よび $\mathrm{Cr}_{7} \mathrm{C}_{3}$ は $\mathrm{Cr}$ 粉末と $\mathrm{C}$ 粉末を用いて作製し た. $\mathrm{Cr}_{3} \mathrm{C}_{2}$ の場合には 14 mass $\% \mathrm{C}, \mathrm{Cr}_{7} \mathrm{C}_{3}$ の場合には 9.5 mass\% $\%$ と若干Cを過剩飞配合し，十分混合した後，7 $\mathrm{MPa}$ で加圧成形し，1個約 $1 \mathrm{~g}$ のディスクを作製した。こ れらを $\mathrm{Ar}$ ガス気流中, $1573 \mathrm{~K} に 21.6 \mathrm{ks}$ 焼成した。焼成 後, 試料を粉末 $\mathrm{X}$ 線回折に上り同定し, それぞれ $\mathrm{Cr}_{3} \mathrm{C}_{2}$ 括 よび $\mathrm{Cr}_{7} \mathrm{C}_{3}$ が生成していることを確認した。

\subsection{2 $\mathrm{Cu}-\mathrm{Zr}$ 系}

出発試料として, 三菱マテリアル知製の $\mathrm{Cu}-\mathrm{Zr}$ 合金 $(\mathrm{Zr}$ 濃度 780 mass ppm，以下単に ppm と記す）を用いた．本合 金は実験直前に硝酸 $(1+1)$ で洗浄した後, 超音波洗浄器に か汿，蒸留水，アルコール，アセトンの順で洗浄しドライヤ 一で冷風乾燥した。上記母合金に適宜無酸素銅を配合し，初 期 $\mathrm{Zr}$ 濃度を調製して実験に供した。

崖化ジルコニウムは市販の Z $\mathrm{rC}$ 粉末(純度 $99 \%$ )を用いた。 実験に際しては，压縮成形後，真空抵抗加熱炉により，温度 $2000 \mathrm{~K}$ に括いて $2 \times 10^{-2} \mathrm{~Pa}$ の減圧下で $7.2 \mathrm{ks}$ 焼成したも のを用いた。

\section{2 溶銅中の $\mathrm{Cr}$ および $\mathrm{Zr}$ の溶解度の求め方}

$\mathrm{Cu}-\mathrm{M}-\mathrm{C} 3$ 元系 $(\mathrm{M}=\mathrm{Cr}$ なは $\mathrm{Zr})$ に Gibbs の相律を適用 すると，独立成分は 3 であるから，3凝縮相平衡の場合，自 由度は 1 となり温度を固定することによりすべての示強変 数 (intensive variable) が固定される.したがって，本実験で は以下の平衡反応を利用した.

\subsection{1 $\mathrm{Cu}-\mathrm{Cr}$ 系}

文献によれば $\mathrm{Cr}$ の炭化物は $\mathrm{Cr}_{3} \mathrm{C}_{2}, \mathrm{Cr}_{7} \mathrm{C}_{3}$, 㧊よび $\mathrm{Cr}_{23} \mathrm{C}_{6}$ の3 種類が存在する16). 本実験ではこれらの5ち $\mathrm{C}-\mathrm{Cr}_{3} \mathrm{C}_{2}$ または $\mathrm{Cr}_{3} \mathrm{C}_{2}-\mathrm{Cr}_{7} \mathrm{C}_{3}$ と溶銅とをそれぞれ平衡させ，溶銅中 の $\mathrm{Cr}$ の溶解度を求めた。

前者の実験では黒鉛るつぼを用いた。この場合，Crの高 濃度側から平衡濃度に接近させる方法により行った。すなわ ち，予備実験 (後述)で得た予想される溶解度より高濃度 $\mathrm{Cr}$ の Cu-Cr 合金を黒鉛るつ汸に上り溶解し，過剩の Crをる つぼから供給される $\mathrm{C}$ と反応させ， $\mathrm{Cr}_{3} \mathrm{C}_{2}$ として析出させる ஆのである.

後者の実験ではボロンナイトライド(BN)るつぼを用いた。 この場合も $\mathrm{Cr}$ の高濃度側 $(\mathrm{H})$ から平衡濃度に接近させる方 法により行ったが, 確認のため低濃度側( $\mathrm{L}$ )から平衡濃度に 接近させる方法も一部行った。すなわち $\mathrm{H}$ は予備実験で得 た予想される溶解度より高濃度 $\mathrm{Cr} の \mathrm{Cu}-\mathrm{Cr}$ 合金を $\mathrm{BN}$ る つぼに $\mathrm{Cr}_{3} \mathrm{C}_{2}$ ととも火入れ合金を溶解し，溶融合金と $\mathrm{Cr}_{3} \mathrm{C}_{2}$ との反応により銅中の過剰の $\mathrm{Cr}$ 勋 $\mathrm{C}_{3}$ として析出させる ものであり，一方 Lでは予想される溶解度上り低濃度 $\mathrm{Cr}$ の $\mathrm{Cu}-\mathrm{Cr}$ 合金と $\mathrm{Cr}_{7} \mathrm{C}_{3}$ を $\mathrm{BN}$ るつぼで溶解し, $\mathrm{Cr}_{7} \mathrm{C}_{3}$ の一部の 分解により $\mathrm{Cr}_{3} \mathrm{C}_{2}$ を析出させ $(\mathrm{Cu}-\mathrm{Cr})-\mathrm{Cr}_{3} \mathrm{C}_{2}-\mathrm{Cr}_{7} \mathrm{C}_{3}$ の 3 凝 縮相平衡に到達させるものである。両方法に上る平衡 $\mathrm{Cr}$ 濃 度は一致するはずである。

なお，これらの平衡到達までの経路の図式的説明について はすでに報告しているので17)，ここでは割愛する.

\subsection{2 $\mathrm{Cu}-\mathrm{Zr}$ 系}

Zr の炭化物は $\mathrm{ZrC}$ のである16)．したがって，予想され る溶解度より高濃度 $\mathrm{Zr}$ の $\mathrm{Cu}-\mathrm{Zr}$ 合金を黒鉛るつぼで溶解 し， $\mathrm{ZrC}$ を析出させ平衡に近つける方法と，純銅を $\mathrm{ZrC}$ と ともに黒鉛るつぼで溶解し，平衡に近づける方法の 2 通り の方法で平衡溶解度を求わた。

\section{3 実験装置および操作方法}

装置の概略図Fig. 1 に示す，反応管は高純度アルミナ 製で，両端はAr ガス導入のための導入管を備えたシリュー ンゴム栓で密閉されている，李た，反応管の下方には試料を 急冷するために，黄銅製の容器が水浴中に設置されている.

用いた黒鉛るつぼは絊度 $99.99 \%$ であり，試料への污染を 防ぐため，予め黒鉛発熱体真空抵抗加熱炉で $2 \times 10^{-2} \mathrm{~Pa} の$ 减圧下， $2000 \mathrm{~K}$ で $7.2 \mathrm{ks}$ 脱ガス処理を施したものである.

試料の溶解には $\mathrm{SiC}$ または $\mathrm{LaCrO}_{3}$ を発熱体とする抵抗加 熱炉を用いた。温度制御には栄光電機㑣製 TPC 型精密温度 調節器を使用し, 実験温度領域で $\pm 3 \mathrm{~K}$ の誤差内で制御した。

\subsection{1 溶銅と $\mathrm{C}-\mathrm{Cr}_{3} \mathrm{C}_{2}$ との平衡実験}

前述のように作製した $\mathrm{Cr}$ 濃度 0.4 1.0 mass\%の Cu-Cr 合金約 $7 \mathrm{~g}$, 外径 $8 \mathrm{~mm}$, 内径 $4 \mathrm{~mm}$, 高さ $76 \mathrm{~mm}$ の黒 鉛るつぼに入れ, 径 $2 \mathrm{~mm}$ の $\mathrm{mo}$ 線に上り炉の均熱带に吊 り下げ，Ar ガス気流中 (流速 $1.7 \times 10^{-6} \mathrm{~m}^{3} \mathrm{~s}^{-1}$ ) で所定温度 (1573, 1673, 1773䄮よび $1873 \mathrm{~K})$ まで昇温した。保持時間 は1.8 39.6 ks の間で変化させた. 試料の冷却は酸化を防 ぐため Ar ガスの流量を $2.0 \times 10^{-5} \mathrm{~m}^{3} \mathrm{~s}^{-1}$ に増加させ，アル ミナ反応管下部のシリューンゴム栓を取り，Mo線を一気に 


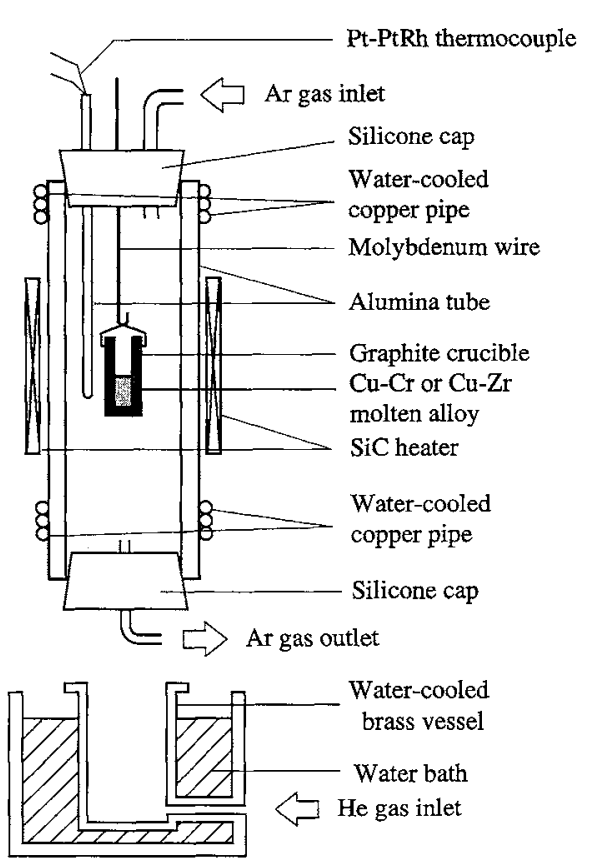

Fig. 1 Schematic diagram of the apparatus for the experiment with a graphite crucible.

押し下げることにより，黒鉛るつ㭱を水冷された黄銅容器中 八素早く入れ，流量 $2 \times 10^{-3} \mathrm{~m}^{3} \mathrm{~s}^{-1}$ で $\mathrm{He}$ ガスを吹き付子る ことにより行った.

\subsection{2 溶銅と $\mathrm{Cr}_{3} \mathrm{C}_{2}-\mathrm{Cr}_{7} \mathrm{C}_{3}$ との平衡実験}

本実験では主に予想される溶銅中の $\mathrm{Cr}$ の平衡溶解度より 高濃度側から平衡飞到達させる実験を1523, 1573, 1623特よ び $1673 \mathrm{~K} の 4$ 温度に対して行ったが，結果の信頼性を確認 するため, 低濃度側から平衡に到達させる実験も1573, 1623 扣よび $1673 \mathrm{~K}$ の 3 温度で各 1 回行った。

まず，高濃度側から平衡に到達させる実験に打いては，予 め作製 した $\mathrm{Cr}$ 濃度 0.8 1.3 mass\%の Cu-Cr 合金約 $3 \mathrm{~g}$ と

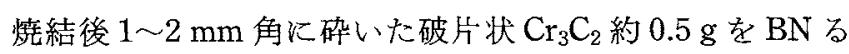
つ涪(外径 $11 \mathrm{~mm}$, 内径 $9 \mathrm{~mm}$, 高さ $30 \mathrm{~mm}$ ) 中に入れ, こ の BNるつ济をさらに黒鉛るつぼ(外径 $23 \mathrm{~mm}$, 内径 19 $\mathrm{mm}$, 高さ $85 \mathrm{~mm}$ ) に入れ, Mo 線で炉の均熱帯に吊り下げ た。

つぎに，低濃度側から平衡に到達させる実験では，Cr 濃 度 0.40 mass \% $\sigma \mathrm{Cu}-\mathrm{Cr}$ 合金と $\mathrm{Cr}_{7} \mathrm{C}_{3}$ を出発物質とし, 上 述のように炉中に設置した。保持時間は $7.2 \sim 43.2 \mathrm{ks}$ の間 で变化させた。両実騃とも冷却方法は $\mathrm{Cu}-\mathrm{C}-\mathrm{Cr}_{3} \mathrm{C}_{2}$ 系の平 衡実験で採用した方法と同じである。

\subsection{3 溶銅と $\mathrm{C}-\mathrm{ZrC}$ との平衡実験}

本実験は平衡時間, 予想される平衡 $\mathrm{Zr}$ 濃度を明らがにす るため，いわゆる尒備実験として種々の実験を行っている がここでは採用したデータを得るための実験方法について のみ述べる。

予備実験で得た予想される溶銅中の $\mathrm{Zr}$ の平衡溶解度を参 考に $\mathrm{Cu}-\mathrm{Zr}$ 母合金 $(\mathrm{Zr}: 780 \mathrm{ppm})$ と無酸素銅を, 全量約 20 $\mathrm{g}$ となるよらに配合し, 黒鉛るつぼ(外径 $20 \mathrm{~mm}$, 内径 12 $\mathrm{mm}$, 高さ $80 \mathrm{~mm}$ ) K $\mathrm{ZrC}$ とと6入れ, 径 $2 \mathrm{~mm} \sigma \mathrm{Mo}$ 線 で炉中均熱帯に吊り下げた。保持温度は1623, 1673, 1723拉

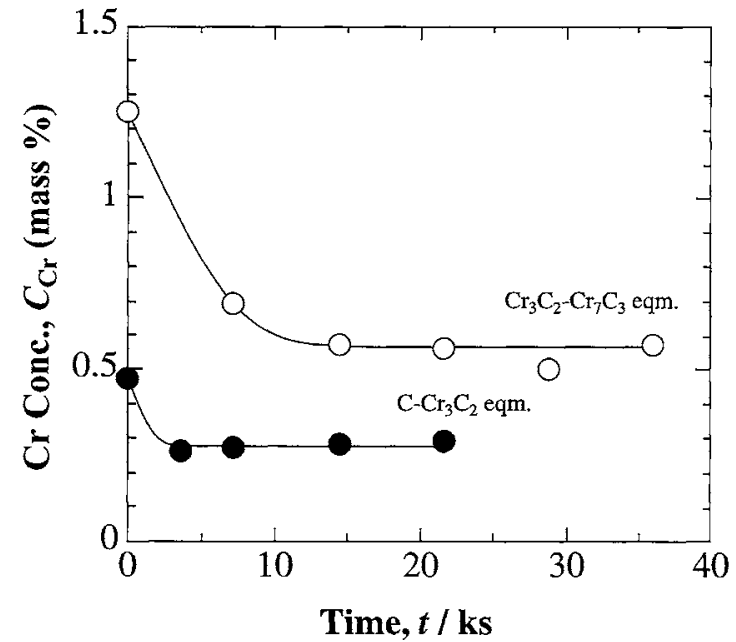

Fig. 2 Relationship between holding time and chromium concentration in liquid copper at $1573 \mathrm{~K}$.

よび $1773 \mathrm{~K} の 4$ 温度で行い，保持時間は $7.2 \sim 72.0 \mathrm{ks}$ の間 で変化させた。試料の急冷は $\mathrm{Cu}-\mathrm{Cr}$ 系の平衡実験の場合に 行った方法と同じである.

\section{4 分 析}

$\mathrm{Cu}$ 中の $\mathrm{Cr}$ 叔よび $\mathrm{Zr}$ の分析は日本ジャーレルアッシュ社 製 ICAP575-II 型高周波誘導結合プラズマ発光分光分析装置 を，酸素分析は LECO 社製 TC-336 酸素窒素同時分析装置 を，また炭素分析は LECO 社製 CS-444 炭素イオウ同時分 析装置を用いて行った

\section{3. 結果および考察}

\section{$3.1 \mathrm{Cu}-\mathrm{Cr}$ 系}

\subsubsection{Cr の溶解度}

$\mathrm{Cu}-\mathrm{Cr}$ 合金と $\mathrm{C}-\mathrm{Cr}_{3} \mathrm{C}_{2}$ との平衡の場合には，まず，初期 Cr 濃度 0.47 mass\%の Cu-Cr 合金を黒鉛るつぼ入れ， $1573 \mathrm{~K}$ にて保持実験を行った。結果をFig. $2\left(\mathrm{C}-\mathrm{Cr}_{3} \mathrm{C}_{2}\right.$ eqm.) k示す。保持時間 $3 \mathrm{ks}$ でほぼ一定值, 約 0.27 mass\%Crを示している。また，冷却後の試料の EPMA 観 察によりCrは合金と黒鉛るつ添の界面に濃縮していること が認められた。つまり $\mathrm{Cr}_{3} \mathrm{C}_{2}$ は主にCrのるつぼ壁への桩散 Kより生成したものと思わ机る。

つぎに，合金と $\mathrm{Cr}_{3} \mathrm{C}_{2}-\mathrm{Cr}_{7} \mathrm{C}_{3}$ との平衡の場合には，初期 $\mathrm{Cr}$ 濃度 1.25 mass\%の Cu-Cr 合金と $\mathrm{Cr}_{3} \mathrm{C}_{2}$ ペレットを $\mathrm{BN}$ るつ注に入れ， $1573 \mathrm{~K}$ Kて前述の2.3.2の方法により保持実 験を行った。結果を同じく Fig. $2\left(\mathrm{Cr}_{3} \mathrm{C}_{2}-\mathrm{Cr}_{7} \mathrm{C}_{3}\right.$ eqm.) ル示 す。これり，14 ks 以上の保持時間で一定值約 0.57 mass\% Crを示していることがわかる.

温度上昇に上る溶解度の増加を考慮して，以上の結果を以 後の実験において溶解に用いる合金の初期 $\mathrm{Cr}$ 濃度を決める ための目安とし，2.3.1叔よび2.3.2の平衡実験を行い，その 結果をるとて Fig. 3 に示した。

Fig. 3 は溶銅中の $\mathrm{Cr}$ の溶解度を $\mathrm{Cr}$ 濃度の対数を檤軸に とり，温度の逆数に対して表したものである. $\mathrm{C}-\mathrm{Cr}_{3} \mathrm{C}_{2}$ と溶 


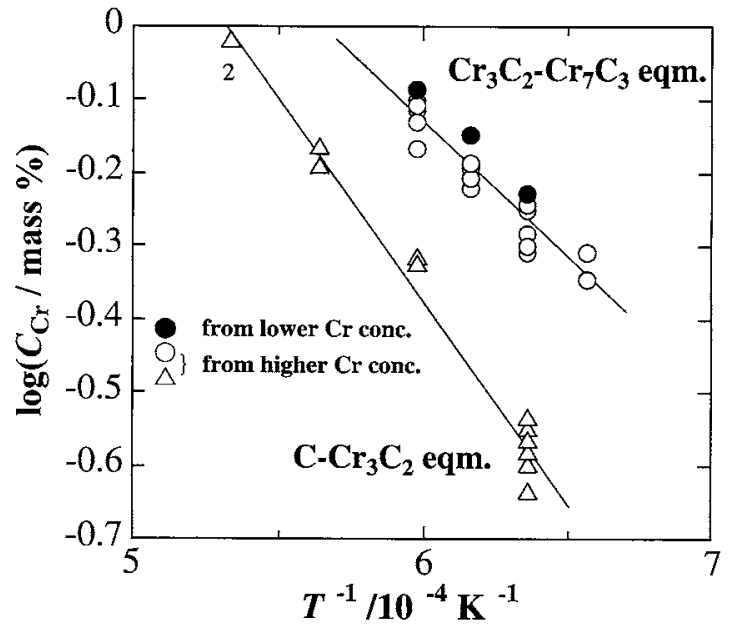

Fig. 3 Temperature dependences of equilibrium chromium concentrations in liquid copper under the coexistence of $\mathrm{C}$ $\mathrm{Cr}_{3} \mathrm{C}_{2}$ and $\mathrm{Cr}_{3} \mathrm{C}_{2}-\mathrm{Cr}_{7} \mathrm{C}_{3}$. Numerical figure represents number of data included in the single point.

銅合金の平衡実験に対しては2.2で述べたように Cr の高濃度 側から平衡溶解度に近づける方法で行い，低濃度側からの奏 験は行わなかったが，これは例光ば $1573 \mathrm{~K}\left(T^{-1}=6.36 \times\right.$ $10^{-4}$ ) の結果は初期 $\mathrm{Cr}$ 濃度が $0.42 \sim 0.83$ mass\%で種々変化 させて行ったものであるが，初期浱度の違いとよる平衡後の 分析濃度の有意差が認められなかったので，本実験条件で十 分に平衡炕達していたと判断したからである。また， $\mathrm{Cr}_{3} \mathrm{C}_{2}-\mathrm{Cr}_{7} \mathrm{C}_{3}$ に対しては平衡確認のため行った低濃度側(い ずれも初期 $\mathrm{Cr}$ 濃度：0.40 mass\%)からの結果を○で示して いる. 各温度とも高漂度 $\mathrm{Cr}$ 側から平衡に近づけたOに比べ て若干高い $\mathrm{Cr}$ 濃度を示している。この原因は明らかでない が，○のばらつきから考党て両者を一致していると見なして 以下の考察を行った。

$\mathrm{C}-\mathrm{Cr}_{3} \mathrm{C}_{2}$ 打よび $\mathrm{Cr}_{3} \mathrm{C}_{2}-\mathrm{Cr}_{7} \mathrm{C}_{3}$ と平衡する溶銅中の $\mathrm{Cr}$ 濃度 を温度の逆数付対して直線近似し, 次式で示撋係を得た。

$\mathrm{C}-\mathrm{Cr}_{3} \mathrm{C}_{2}$ との平衡に対して,

$\log (\operatorname{mass} \% \mathrm{Cr})=2.97-5580 T^{-1}( \pm 0.032)(1573-1873 \mathrm{~K})$

$\mathrm{Cr}_{3} \mathrm{C}_{2}-\mathrm{Cr}_{7} \mathrm{C}_{3}$ との平衡以対して,

$\log (\operatorname{mass} \% \mathrm{Cr})=2.10-3710 T^{-1}( \pm 0.027)(1523-1673 \mathrm{~K})$

Fig. 4 はこの結果を縦軸炕温度，横軸に $\mathrm{Cu}-\mathrm{Cr}$ 合金中の $\mathrm{Cr}$ の濃度 (mass\%)をとり表したものである。同図には Cr の酸化物 $\mathrm{Cr}_{2} \mathrm{O}_{3}$ が析出する領域が点線で示されているが， これは以下のデータを用い求めた。

計算に用いるデータとして,

$$
\begin{aligned}
& 3 \mathrm{Cr}_{3} \mathrm{C}_{2}(\mathrm{~s})+2 \mathrm{Cr}_{2} \mathrm{O}_{3}(\mathrm{~s})=13 \mathrm{Cr}(\mathrm{s})+6 \mathrm{CO}(\mathrm{g}) \\
& \Delta G^{\circ} / \mathrm{J}=1795000-959.9 T^{18)}
\end{aligned}
$$

および

$$
\begin{aligned}
& \mathrm{Cr}_{7} \mathrm{C}_{3}(\mathrm{~s})+\mathrm{Cr}_{2} \mathrm{O}_{3}(\mathrm{~s})=9 \mathrm{Cr}(\mathrm{s})+3 \mathrm{CO}(\mathrm{g}) \\
& \Delta G^{\circ} / \mathrm{J}=936700-472.8 T^{18)}
\end{aligned}
$$

さらに, 溶銅中の $\mathrm{Cr}$ の無限希薄の活量係数 $\left(\gamma_{\mathrm{C}_{\mathrm{r}}}^{\circ}\right)$ として Inouye $5^{11)}$ の

$$
\ln \gamma_{\mathrm{cr}}^{\circ}=1.17 \times 10^{4} T^{-1}-4.41
$$

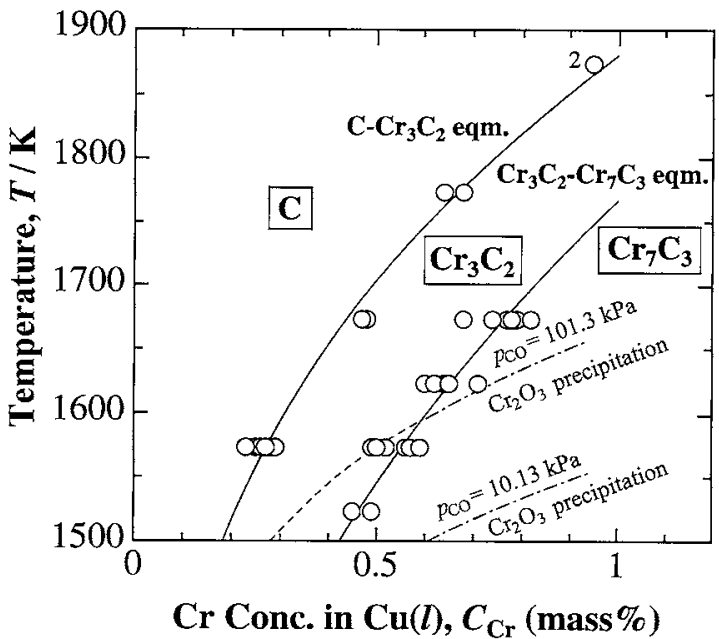

Fig. 4 Solubilities of chromium in liquid copper in equilibria with $\mathrm{C}-\mathrm{Cr}_{3} \mathrm{C}_{2}$ and $\mathrm{Cr}_{3} \mathrm{C}_{2}-\mathrm{Cr}_{7} \mathrm{C}_{3}$. Numerical figure represents the number of data included in the single point.

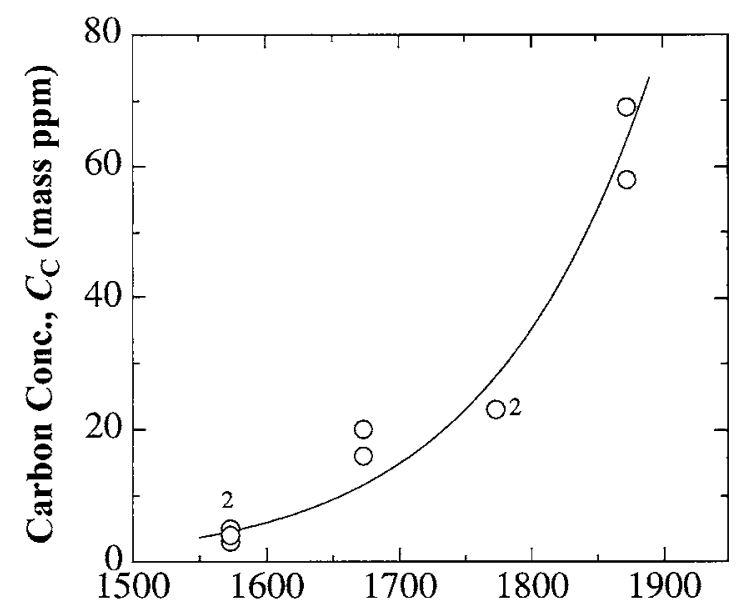

Temperature, $T$ / K

Fig. 5 Solubilities of carbon in liquid $\mathrm{Cu}-\mathrm{Cr}$ alloys in equilibrium with $\mathrm{C}-\mathrm{Cr}_{3} \mathrm{C}_{2}$. Numerical figures represent the number of data included in the single point.

を採用した。これらのデータから Crの酸化物と炭化物は相 互溶解度をもたないと仮定することにより雾团気の $p_{\mathrm{C}_{0}}$ が $101.3 \mathrm{kPa}$ と $10.13 \mathrm{kPa}$ 亿対して計算を行った.

図より黑鉛るつ活を用いて $\mathrm{Cu}-\mathrm{Cr}$ 合金を溶解する場合, $\mathrm{Cr}$ の炭化物が生成しない溶解条件は $\mathrm{C}-\mathrm{Cr}_{3} \mathrm{C}_{2}$ 平衡で決まる $\mathrm{Cr}$ の溶解度曲線の左側であること,さらに系内の $\mathrm{CO}$ 分压 を下げることにより酸化物も生成しないことがわかる。

\subsection{2 炭素濃度}

Fig. 5 K C- $\mathrm{Cr}_{3} \mathrm{C}_{2}$ と平衡する合金中の $\mathrm{C}$ 溶解度之温度の 関係を示した。分析 C濃度は $1573 \mathrm{~K} て ゙ 3 〜 5 \mathrm{ppm}$ から $1873 \mathrm{~K}$ で 60〜70 ppm まで增加しているが，これは，Cuに 比べて C との親和力が強い $\mathrm{Cr}$ の溶解度が温度上昇に伴い, 急激に増加しているためであると思われる。

な拈, $\mathrm{Cr}_{3} \mathrm{C}_{2}-\mathrm{Cr}_{7} \mathrm{C}_{3}$ 平衡に対しては, いずれの温度に対し ても $10 \mathrm{ppm} \mathrm{C}$ 以下となり, 炭素分析の誤差のためか, 温度 との相関は認められなかった。 


\section{1 .3 酸素濃度}

合金試料中の酸素濃度は $\mathrm{C}-\mathrm{Cr}_{3} \mathrm{C}_{2}$ との平衡の場合には温 度に関係なく $2 \sim 3 \mathrm{ppm}, \mathrm{Cr}_{3} \mathrm{C}_{2}-\mathrm{Cr}_{7} \mathrm{C}_{3}$ 平衡に対しては $2 \sim 8$ $\mathrm{ppm}$ を示した. 本結果から $\mathrm{Cr}$ の酸化物の生成はなく溶解酸 素として存在していたものと考えられるが，10 ppm 以下の 酸素分析に対してはまだ再現性がそしく，酸素濃度に対する 考察は行わなかった。

\section{2. $\mathrm{Cu}-\mathrm{Zr}$ 系}

\subsection{1 $\mathrm{Zr}$ の溶解度}

平衡到達委での時間を調べる目的で，1673 KK和いて初 期 $\operatorname{Zr}$ 濃度 $780 \mathrm{ppm} の \mathrm{Cu}-\mathrm{Zr}$ 母合金を墨鉛るつぼ中で溶解

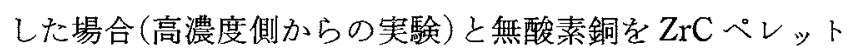
とともに黒鉛るつぼ中で溶解した場合 (低濃度側からの実験) の溶解時間に対する溶銅中の $\mathrm{Zr}$ 濃度の变化を求めそれぞれ Fig. 6 括よびFig. 7 に示した。高濃度側からの実験の場合， 溶銅中の Zr 濃度は時間とともに単調に減少して和り，保持

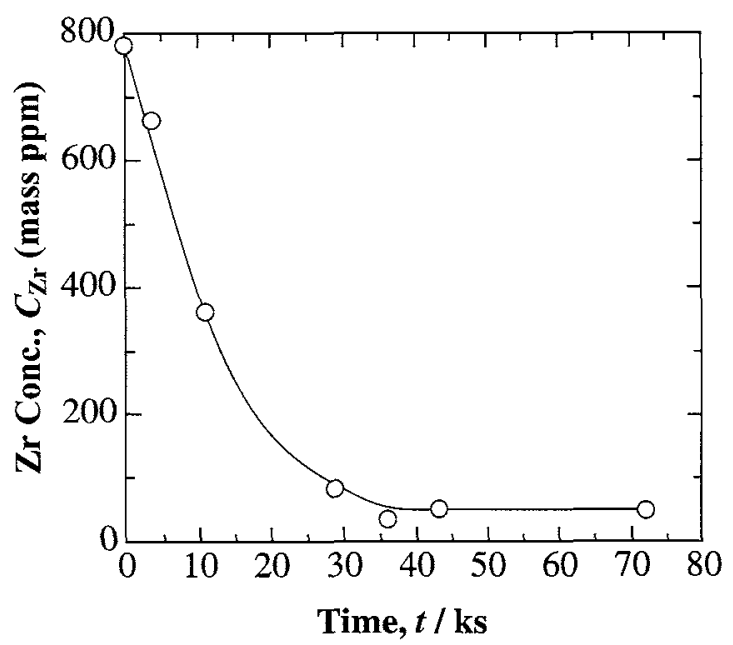

Fig. 6 Time dependence of zirconium concentration in liquid copper held in the graphite crucible at $1673 \mathrm{~K}$. Copper alloy with 780 mass ppm $\mathrm{Zr}$ was used as a starting material.

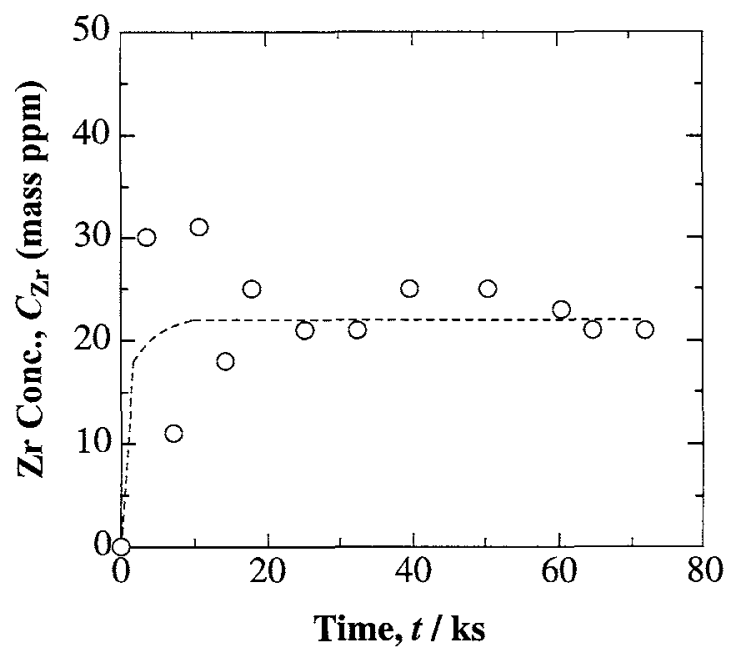

Fig. 7 Time dependence of zirconium concentration in liquid copper held in the graphite crucible with $\mathrm{ZrC}$ at $1673 \mathrm{~K}$. Oxygen free copper was used as a starting material.
時間 $40 \mathrm{ks}$ 以上で一定值約 $50 \mathrm{ppm} \mathrm{Zr}$ 杂している.

一方，低濃度側からの実験の場合，Fig. 7 に示したよう

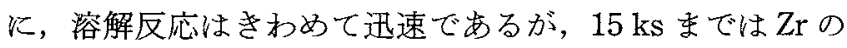
分析值のばらつきはかなり大きく，15ks 経過後に汪ぼ一定 の值 $22 \mathrm{ppm} \mathrm{Zr}$ 杂示している。

前述したように，これら2つの結果は平衡に和いては一 致するはずであるが，両者のZ Zr濃度には明らかに差があ り 高濃度側からの Zr 濃度は低濃度側からのそれに比べ高 い值を示している，前者の冷却後のるつぼと合金の界面の EPMA 観察を行ったところ，過剩の $\mathrm{Zr}$ がC と反応して生 成する $\mathrm{ZrC}$ が $\mathrm{Cr}$ の昜合と同様にるつ辟に析出しているの が認められた。上記の $\mathrm{Zr}$ の濃度差はこの $\mathrm{ZrC}$ がきわめて緻 密であったため合金一黒鉛- $\operatorname{ZrC} の 3$ 相平衡を阻害したのが 原因ではないかと思われる。

Fig. 8 に1723抗よび $1773 \mathrm{~K}$ の結果ととすにまとめて示し た。図中 $\square$ は初期 $\mathrm{Zr}$ 濃度 $780 \mathrm{ppm} の \mathrm{Cu}-\mathrm{Zr}$ 母合金を黑鉛

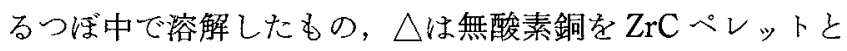
もに溶解した結果である。田は各温度ともかなりばらつさが

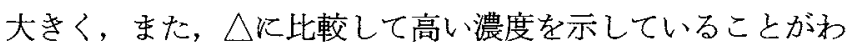
かる。

そこで，両者の中間の $\mathrm{Zr}$ 濃度となるよらに $\mathrm{Cu}-\mathrm{Zr}$ 母合金 $(Z \mathrm{r}: 780 \mathrm{ppm})$ と無酸素銅を配合し，2.3.3で述べた方法(グ ラファイトるつぼで $\mathrm{ZrC}$ ともに溶解)により平衡実験を行 い, Fig. 9 に示す $\log (\mathrm{ppm} Z \mathrm{r})$ と $1 / T$ の関係を得た。多少 ばらつきはあるが，次に示吉直線関係が得られた。

$$
\log (\mathrm{ppm} \mathrm{Zr})=7.47-9.93 \times 10^{3} T^{-1}( \pm 0.055)
$$

$$
(1623-1773 \mathrm{~K})
$$

Fig. 10 は縦軸に温度，横軸に $\mathrm{Cu}-\mathrm{Zr}$ 合金中の $\mathrm{Zr}$ の濃度 (ppm)を示したもので岗る。図には Cr の場合と同様に式 (7)〜(9)のデータを用いて計算により求めた $\mathrm{ZrO}_{2}$ 析出の 境界線を示している。

$$
\begin{array}{r}
2 \mathrm{C}(\mathrm{s})+\mathrm{ZrO}_{2}(\mathrm{~s})=\mathrm{Zr}(\mathrm{s})+2 \mathrm{CO}(\mathrm{g}) \\
\left.\Delta G^{\circ} / \mathrm{J}=847500-345.6 T^{18}\right) \\
2 \mathrm{ZrC}(\mathrm{s})+\mathrm{ZrO}_{2}(\mathrm{~s})=3 \mathrm{Zr}(\mathrm{s})+2 \mathrm{CO}(\mathrm{g}) \\
\Delta G^{\circ} / \mathrm{J}=1245000-366.0 T^{18)}
\end{array}
$$

$\mathrm{Cu}-\mathrm{Zr}$ 合金の活量に関する研究は，著者らの知る限り

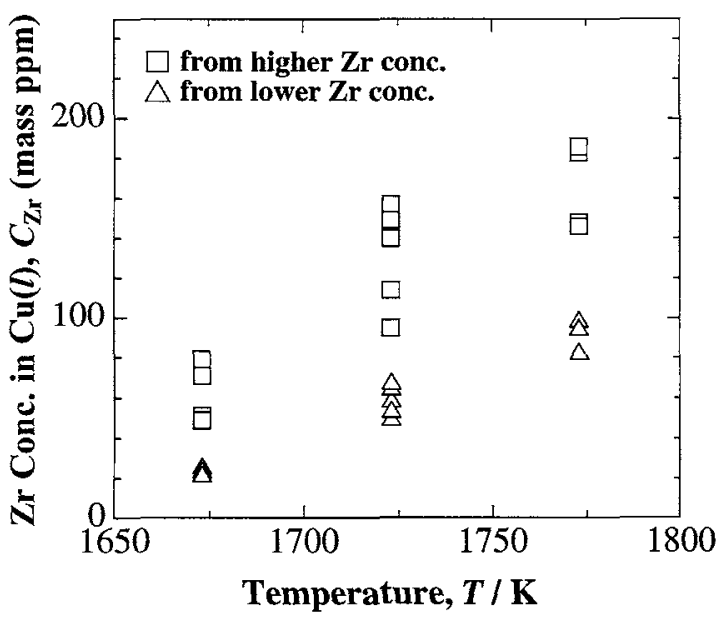

Fig. 8 Temperature dependence of solubility of zirconium in liquid copper in the presence of $\mathrm{C}-\mathrm{ZrC}$. 


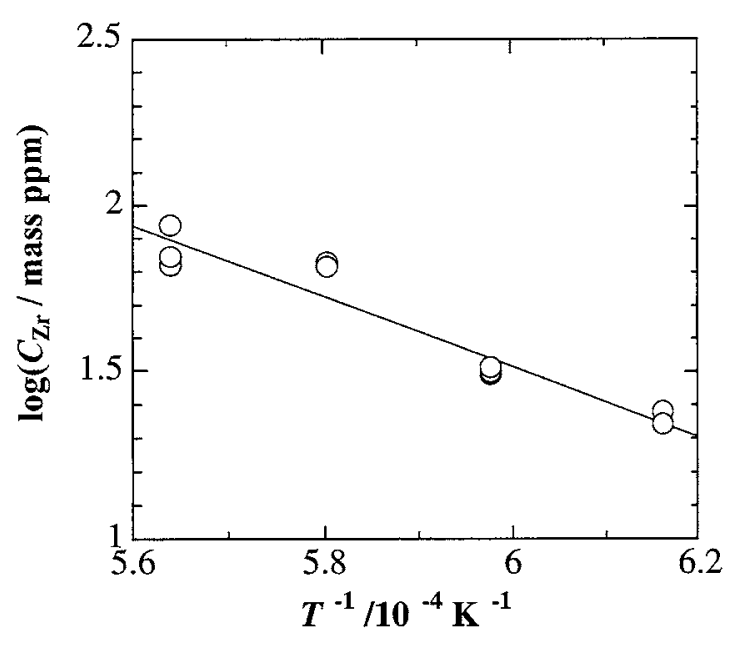

Fig. 9 Temperature dependence of equilibrium zirconium concentration in liquid copper in equilibrium with $\mathrm{C}-\mathrm{ZrC}$.

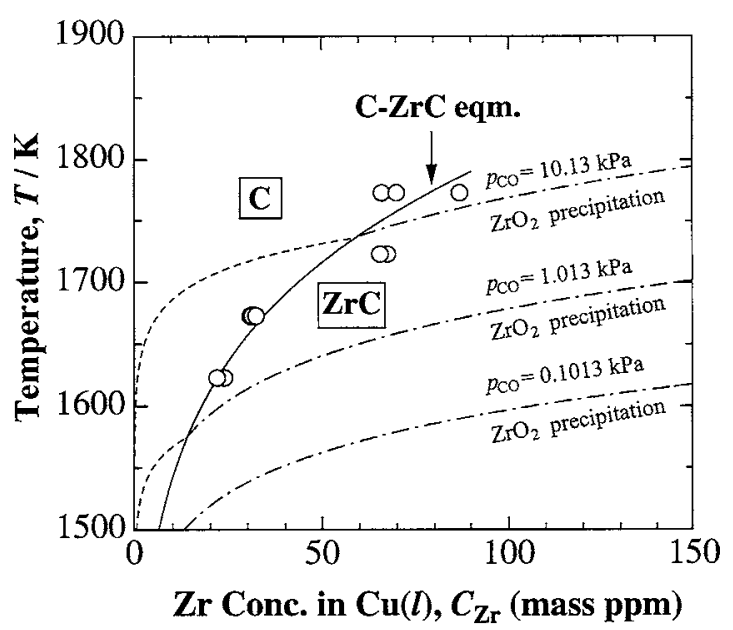

Fig. 10 Solubilities of zirconium in liquid copper in equilibrium with $\mathrm{C}-\mathrm{ZrC}$.

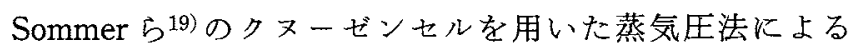
$1499 \mathrm{~K}$ に和ける報告のみである。彼らは Cuの活量のみを 求めているため，Gibbs-Duhem の関係を用いて $\mathrm{Zr}$ の活量 を算出した。この結果より $\mathrm{Zr}$ の無限希薄に㧧ける $\mathrm{Zr}$ の活 量係数を求め, 正則溶液近似により次式を算出した.

$$
\ln \gamma_{\mathrm{Zr}}^{\circ}=-5.8 \times 10^{3} T^{-1}
$$

図から明らかなよらに，黒鉛の存在下では溶銅中への $\mathrm{Zr}$ の溶解度はきわめて小さい値となり $1800 \mathrm{~K}$ 近傍の高温でも $100 \mathrm{ppm}$ 以下であり，こ机は $\mathrm{ZrC}$ がきわめて安定な化合物 であることに因っている，したがって，溶解雾囲気の CO 分 圧を $\mathrm{Cr}$ の場合に比較して 2 桁程度下げなければ， $\mathrm{ZrO}_{2}$ の 生成が避けられないことがわかる。

\subsection{2 炭素濃度}

Fig. 11 KC-ZrC と平衡する合金中のC濃度と温度の関 倸を示した。分析 C 濃度は $10 \mathrm{ppm}$ 以下であり, 各温度に おいてそれぞればらつきがかなり大きいが，温度の上昇とと もに溶解度は増える傾向が認められた。

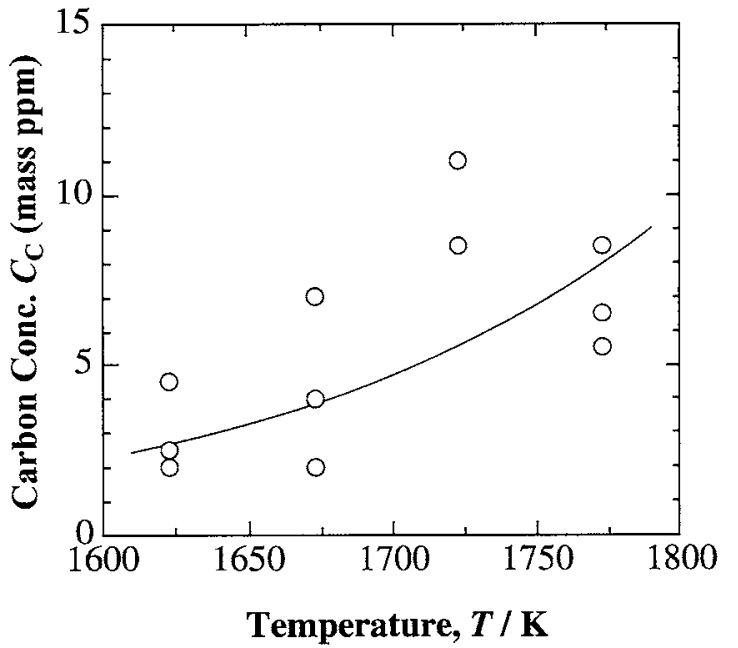

Fig. 11 Solubilities of carbon in liquid $\mathrm{Cu}-\mathrm{Zr}$ alloys in equilibrium with $\mathrm{C}-\mathrm{ZrC}$.

\subsection{3 酸素濃度}

合金試料中の酸素濃度は各温度とも $10 \mathrm{ppm}$ 以下であった が，温度に対して，明確な依存性は認められなかった。

\section{4. 結言}

活性金属にクロムとジルコニウムを選び，銅と活性金属の 合金を溶製する場合に酸化物，炭化物などの非金属介在物を 生成しない，いわゆる高清浄合金を製造するための基礎研究 として，高温で強い脱酸力を有する黒鉛をるつぼとして用 い，それぞれの金属の炭化物 $\left(\mathrm{Cr}_{3} \mathrm{C}_{2}\right.$ 和よび $\left.\mathrm{ZrC}\right)$ を生成する までの溶銅中への Cr㧊よび $\mathrm{Zr}$ 溶解度を求めた. Crに関し ては $\mathrm{Cr}_{3} \mathrm{C}_{2}$ よりもさらに炭素の活量が小さい $\mathrm{Cr}_{7} \mathrm{C}_{3}$ が析出 するまでの Cr の溶解度も求め, 以下の知見を得た。

(1) $\mathrm{C}-\mathrm{Cr}_{3} \mathrm{C}_{2}$ と平衡する溶銅中の $\mathrm{Cr}$ の溶解度の対数は, 温度の逆数に対して次の直線関係で表された。 $\log (\operatorname{mass} \% \mathrm{Cr})=2.97-5580 T^{-1}( \pm 0.032)(1573-1873 \mathrm{~K})$ また, $\mathrm{Cr}_{3} \mathrm{C}_{2}-\mathrm{Cr}_{7} \mathrm{C}_{3}$ との平衡に対して， $\log (\operatorname{mass} \% \mathrm{Cr})=2.10-3710 T^{-1}( \pm 0.027)(1523-1673 \mathrm{~K})$ を得た。

(2) $\mathrm{C}-\mathrm{Cr}_{3} \mathrm{C}_{2}$ と平衡する $\mathrm{Cu}-\mathrm{Cr}$ 液体合金中の C の溶解度 は $1573 \mathrm{~K} て ゙ 3 〜 5 \mathrm{ppm}$ から $1873 \mathrm{~K} の 60 \sim 70 \mathrm{ppm}$ まで増加 した。これは温度上昇に伴う $\mathrm{Cr}$ の溶解度の急激な増加が起 因していると思われる， $\mathrm{Cr}_{3} \mathrm{C}_{2}-\mathrm{Cr}_{7} \mathrm{C}_{3}$ との平衡に対しては，

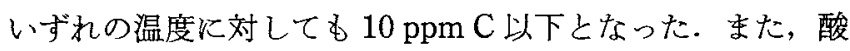
素の溶解度は温度に関係なく $\mathrm{C}-\mathrm{Cr}_{3} \mathrm{C}_{2}$ との平衡に対しては $2 \sim 3 \mathrm{ppm}$, 同じく $\mathrm{Cr}_{3} \mathrm{C}_{2}-\mathrm{Cr}_{7} \mathrm{C}_{3}$ との平衡に対しては $2 \sim 8$ ppmであった.

(3) $\mathrm{C}-\mathrm{ZrC}$ と平衡する溶銅中の $\mathrm{Zr}$ の溶解度の対数は, 温 度の逆数に対して次の直線関係で表された.

$$
\log (\mathrm{ppm} \mathrm{Zr})=7.47-9.93 \times 10^{3} T^{-1}( \pm 0.055)
$$

$$
(1623-1773 \mathrm{~K})
$$

(4) $\mathrm{C}-\mathrm{ZrC}$ と平衡する $\mathrm{Cu}-\mathrm{Zr}$ 液体合金中の C の溶解度は $10 \mathrm{ppm}$ 以下であったが，温度の上昇とともに増加する傾向 が認められた。また，酸素の溶解度はすべての本実験温度に 
対して $10 \mathrm{ppm}$ 以下であったが，溶解度と温度との相関は誋 められなかった。

（5）熱力学データを用い， Cr 和よび Zr の酸化物が析出し ない溶解雾囲気中の CO 分圧と温度, 溶銅中の Cr 和よび $\mathrm{Zr}$ 濃度の関係について求め, 炭化物, 酸化物ともに析出しない 溶解条件を確立した。

\section{文献}

1) T. Kuroyanagi: J. Japan Inst. Light Metals, 37 (1987), 313-326.

2) M. Tsuji: Bulletin of the Japan Inst. Metals, 27(1988), 899906.

3) S. Nishiyama: ibid., 28(1989), 137-145.

4) T. Igarashi: ibid., 28(1989), 63-69.

5) R. Futatsuka: J. Association Materials Eng. Resorces, 3 (1990), 136-147.

6) K. Ishida, Y. Kato and M. Hanada: J. Japan Copper and Brass Research Assoc., 22(1983), 216-222.
7) H. Abe, G. Sasaki, T. Matsui, A. Sugino and S. Tatsumi: Hitachi Densen, 8(1989), 39-44.

8) M. Hamalainen, K. Jaaskelainen, R. Luoma, M. Nuotio, P. Taskinen and O. Teppo: CALPHAD, 14(1990), 125-137.

9) K. Ono, S. Nishi and T. Oishi: Trans. JIM, Met., 25(1982), 810-814.

10) L. Timberg and J. M. Toguri: J. Chem. Thermodynamics, 14(1982), 193-199.

11) T. K. Inouye, H. Fujiwara and M. Iwase: Met. Trans. B, 22B (1991), 475-480.

12) S. Nishikawa, K. Nagata and S. Kobayashi: J. Japan Inst. Met., 30 (1966), 302-307.

13) R. O. Williams: Trans. ASM, 52(1960), 530-544.

14) T. Maruta: J. Japan Inst. Met., 25(1961), 531-535.

15) M. J. Saarivirta: Trans. AIME, 218(1960), 431-437.

16) T. B. Massalski, Editor in Chief: Binary Alloy Phase Diagrams 2nd ed., ASM International, vol. 1 (1992), 837-838.

17) M. Horiguchi, H. Fukumura, H. Ishida, K. Ichii and T. Oishi: SHIGEN-TO-SOZAI, 114(1998), 739-744.

18) A. Roine: Outokumpu HSC Chemistry for Windows Chemical Reaction and Equilibrium Software with extensive Thermochemical Database, (1994).

19) F. Sommer and D. K. Choi: Z. Metallk., 80(1989), 263-269. 